\title{
Selection Parameters for Improving the Seed Cotton Yield and Fibre Quality Traits in American Cotton (Gossypium hirsutum L.)
}

\author{
M. Gnanasekaran* and K. Thiyagu
}

Tamil Nadu Agricultural University, Cotton Research Station, Srivilliputtur-626 135, India

*Corresponding author

\begin{abstract}
A B S T R A C T
Information on the effect of different yield components on improvement of yield will be crucial in any selection programme. Thirty four genotypes of American cotton (Gossypium hirsutum L.) were utilized to study the genetic variability and correlation of yield, its components and fibre properties and data recorded were analyzed to understand the relative contribution of different yield components in enhancing the yield and fibre quality.

Study revealed high heritability observed for days to first flowering, days to fifty percent flowering, number of monopodia per plant, number of bolls per plant, ginning percentage, upper half mean length, bundle strength, fibre fineness, uniformity index and seed cotton yield. Number of monopodia per plant, number of bolls per plant and seed cotton yield shows high heritability coupled with high genetic advance over mean indicating the preponderance of additive gene action in the inheritance of these traits. Traits such as days to first flowering, days to fifty percent flowering, ginning percentage, ginning percentage, upper half mean length, bundle strength and uniformity index in which high heritability accompanied by low genetic advance was recorded indicates the effect of non-additive gene action. Significant positive association of plant height, number of bolls per plant, boll weight and seed index was observed with seed cotton yield per plant. Association of traits inter se revealed the positive and significant association of number of bolls per plant with seed index; Boll weight with seed index, lint index; seed index with fibre fineness was observed. Path coefficient analysis revealed that days to first flowering, plant height and lint index have positive and very high direct effect on seed cotton yield. Information generated on the relationship between yield components, fibre quality and seed cotton yield will help the crop breeder in enhancing the efficiency of selection.
\end{abstract}

Keywords

Correlation, $G$.

hirsutum,

Variability, Yield

components

Article Info

Accepted:

12 September 2020

Available Online:

10 October 2020

\section{Introduction}

'White gold' is the popular term assigned to indicate the importance of cotton crop. Cotton (Gossypium hirsutum L.) is a predominant commercial fibre crop popular among the farming community due to its higher yield and superior fibre quality. For the past few decades the export of textile products increased steadily, correspondingly textile industry has also grown in faster rate and therefore high yielding superior quality cotton varieties/hybrids have to be bred to promote the export in order to enhance the foreign exchange. Further, recent advances in spinning technology demands better fibre 
quality with improved fibre length and bundle strength to produce better quality yarn. Hence, the genotypes with high yield and improved fibre properties are needed to be developed to meet the ever-growing demands of textile industries. In any crop, improvement of yield will be the first and foremost objective of plant breeding. Yield is a complex biometrical trait and its genetic analysis is rather difficult. Seed cotton yield is a resultant product of all its component traits and it could be improved by exploiting the positive influence of yield components. Germplasm, which is a prerequisite for any breeding programme, serves as a valuable source material as it provides scope for building of genetic variability. Study of variability, heritability and genetic advance in the germplasm will help to ascertain the real potential value of the genotype. Since several economic characters including yield in cotton are polygenically controlled, it is necessary to partition the observed overall phenotypic variability into heritable (genetic) and nonheritable (environment) components with the help of genetic coefficient of variation and heritability. Thus, estimation of expected genetic advance may help to select particular population for further selection and improvement. Hanson et al., (1956) proposed heritability in broad sense as the ratio of genotypic variance of a particular character to its phenotypic variance is a function of its heritability, selection pressure and variance existing in the base population. Though the heritability is the relative value of the selection based on phenotypic expression of a character, the genetic advance is more useful in judging the actual value of selection as shown by Johnson et al., (1955). Further, the information on nature of association of different yield contributing characters generated out of the studies will serve as an effective selection procedure for improving the yield indirectly. Hence this present study was planned to assess the genetic variability, correlation and path analysis for various yield and fibre quality characters in a set of genotypes.

\section{Materials and Methods}

The present research work was carried out during winter 2019-20 in the experimental field of Cotton Research Station, Tamil Nadu Agricultural University, Srivilliputtur, Tamil $\mathrm{Nadu}$, India under irrigated condition.

\section{Hybrid development}

Twelve parents, among which two lines viz., SVPR 2 and GJHV 370 and ten testers viz., PBH 116, CSH 3419, CPD 1702, TCH 1828, RAH 0603, RS 2913, F 2596, BGDS 0607, TSH 325 and Suraj were used for crossing. Each of the line was crossed with all the ten testers individually in a line $\mathrm{x}$ tester mating design to develop twenty hybrids during winter, 2018 at Cotton Research Station, Srivilliputtur. Thus the twenty intra-hirsutum crosses were produced using conventional hand emasculation and pollination method developed by Doak (1934). Hybridization programme was continued for twenty five days to get sufficient quantity of crossed bolls and they were collected separately and ginned to obtain $F_{1}$ seeds. Simultaneously, parental seeds were also produced by selfing selected plants.

\section{Field layout}

Twenty hybrids along with twelve parents and two check hybrids (RCH 659 BG II and Mallika NBt.) were raised during winter 2019-20. Experimental materials were raised in three replications in a randomized block design (RBD) with each cross in single row of $4.5 \mathrm{~m}$ length and spacing of $100 \mathrm{~cm}$ between rows and $45 \mathrm{~cm}$ between plants. Recommended agronomic practices and need based plant protection measures were followed to obtain good crop stand. 


\section{Data recording}

Five competitive plants from each genotype were selected in the parents, $F_{1} s$ and check hybrids at random per replication and were labeled with tags for recording the biometrical observations.

The average values of the observations from these five plants represented the mean of that genotype per replication. Thus, a total of 34 genotypes were evaluated for all the 16 characters viz., days to first flowering, days to fifty percent flowering, plant height $(\mathrm{cm})$, number of monopodia per plant, number of sympodia per plant, number of bolls per plant, boll weight $(\mathrm{g})$, seed index, lint index, ginning percentage (\%), seed cotton yield, upper half mean length $(\mathrm{mm})$, bundle strength $(\mathrm{g} / \mathrm{tex})$, fibre fineness $(\mu)$, uniformity index $(\%)$ and fibre elongation $(\%)$.

Observations on five fibre quality traits in each replication were recorded with ten grams of lint sample in High Volume Instrument (HVI) under HVI mode.

\section{Statistical analysis}

The means for all the observed parameters were worked out and were further subjected to Analysis of variance (ANOVA) according to Johnson et al., (1955). The genotypic and phenotypic coefficients of variation were calculated according to the formula given by Falconer (1981). Heritability $\left(\mathrm{h}^{2}\right)$ in the broad sense was calculated according to the formula given by Allard (1960). Genetic advance was estimated by the following formula given by Burton (1952) from the heritability. Correlation coefficients at phenotypic and genotypic level were calculated as per procedure given by Al-Jibouri et al., (1958). Path analysis was carried out as suggested by Dewey and Lu (1959), respectively.

\section{Results and Discussion}

\section{Variability studies}

The analysis of variance (Table 1) revealed significant differences among the thirty four genotypes for all the characters studied indicating that the data generated from the above diverse materials will yield reliable information's. This implied that there is good scope for further improvement in cotton genotypes. The results pertaining to genetic parameters viz., phenotypic coefficient of variation (PCV), genotypic coefficient of variation $(\mathrm{GCV})$, broad sense heritability $\left(\mathrm{h}^{2}\right)$ and genetic advance over mean for all the sixteen characters are furnished in Table 2. The phenotypic coefficient of variation which measures total variation was found to be greater than genotypic coefficient of variation for all the characters indicated some degree of environmental influence on the traits. These findings were also supported by Pujer et al., (2014), Sunayana et al., (2017), Gnanasekaran et al., (2018) and Praveen Sampath Kmar et al., (2019). In the present study, high estimate of phenotypic coefficient of variation (PCV) and genotypic coefficient of variation (GCV) was observed for seed cotton yield per plant $(24.79 \%$ and $23.04 \%)$ and number of monopodia per plant $(61.17 \%$ and $56.64 \%$ ) while number of bolls per plant showed moderate PCV and GCV. Moderate estimates of PCV and low GCV were observed for traits like seed index $(10.90 \%$ and $4.97 \%)$ and lint index $(11.74 \%$ and $7.57 \%$ ) whereas the traits like days to first flowering (3.83\%, and $3.18 \%$ ), days to fifty percent flowering $(3.82 \%$ and $3.06 \%)$, plant height $(6.79 \%$ and $4.91 \%)$, number of sympodia per plant $(7.59 \%$ and $4.47 \%)$, boll weight $(9.37 \%$ and $6.84 \%)$, ginning percentage $(7.54 \%$ and $5.96 \%)$, upper half mean length $(3.13 \%$ and $3.12 \%)$, bundle strength $(2.56 \%$ and $2.54 \%)$, fibre fineness (7.64\% and $7.52 \%)$. uniformity index $(0.51 \%$ 
and $0.50 \%)$ and fibre elongation $(1.72 \%$ and $1.17 \%$ ) exhibited low PCV and GCV. There existed a close agreement between PCV and GCV for most of the traits indicating that the observed variation could largely be due to genetic and there was only less influence of environmental effects in general. This reflects on the reliability of the selection based on the phenotypic performance.

High heritability value was observed for characters like days to first flowering $(68.7 \%)$, days to fifty percent flowering $(64.1 \%)$, number of monopodia per plant $(85.8 \%)$, number of bolls per plant $(80.1 \%)$, ginning percentage $(81.10 \%)$, upper half mean length (99.5\%), bundle strength $(98.0 \%)$, fibre fineness $(96.8 \%)$ uniformity index (96.5\%), and seed cotton yield (86.4\%). This finding was agreed with earlier finding of Pujer et al., (2014). Praveen Sampath Kumar et al., (2019) reported the same results for days to fifty percent flowering, number of bolls per plant, ginning percentage, upper half mean length, bundle strength, fibre fineness and seed cotton yield. Gnanasekaran et al., (2018) have also reported similar results for days to fifty percent flowering, number of bolls per plant, upper half mean length, bundle strength, fibre fineness and seed cotton yield. Plant height (52.2\%), number of sympodia per plant $(34.7 \%)$, boll weight $(53.4 \%)$, lint index $(41.6 \%)$, fibre elongation $(46.3 \%)$ showed moderate estimates of heritability. These results are in agreement with the results reported by Sunayana et al., (2017) for plant height; Eswari et al., (2017) and Gnanasekaran et al., (2018) for number of sympodia per plant; Rama Reddy and Sharma (2014) for boll weight; Praveen Sampath Kumar et al., (2019) for lint index. Heritability estimates along with genetic advance would be more useful in predicting yield under phenotypic selection than heritability estimates alone as suggested by Johanson et al., (1955) and Swarup and
Chaugale (1962). If heritability is mainly due to non-additive gene effect, the expected genetic advance would be low, and if there is additive gene effect, a high genetic advance may be expected (Panse, 1957). In the present investigation high heritability coupled with high genetic advance as percentage of mean was observed for number of monopodia per plant $(85.8 \%, 108.05 \%)$, number of bolls per plant $(80.1 \%, 29.8 \%)$, and seed cotton yield (86.4\%, 44.13\%) indicating the preponderance of additive gene action in the inheritance of these traits. Pujer et al., (2014), Eswari et al., (2017), Sunayana et al., (2017) and Praveen Sampath Kumar et al., (2019) reported high heritability and high genetic advance as percentage of mean for number of bolls per plant, seed cotton yield revealed the influence of additive gene action for these traits. Hence the improvement of these traits can be made through direct phenotypic selection. The traits such as days to first flowering $(68.7 \%, 5.43)$, days to fifty percent flowering $(64.1 \%, 5.05 \%)$, ginning percentage $(62.6 \%, 9.72 \%)$, upper half mean length $(99.5 \%, 6.42 \%)$, bundle strength $(98.0 \%, 5.18 \%)$ and uniformity index $(96.5 \%$, $1.01 \%)$ in which high heritability accompanied by low genetic advance was observed indicates the effect of non additive gene action and hence heterosis breeding may be rewarding for these traits. Gnanasekaran et $a l$. , (2018) for days to fifty percent flowering; Praveen Sampath Kumar et al., (2019) for days to first flowering, ginning percentage, upper half mean length, bundle strength and Pujer et al., (2014) for uniformity index reported the similar results.

\section{Correlation studies}

Computation of correlation between yield and yield attributing traits is of considerable importance in plant selection. The genotypic and phenotypic correlation co-efficient between yield and its components were 
presented in Table 3. Total of sixteen traits studied, four traits namely, plant height (0.443), number of bolls per plant (0.688), boll weight (0.467) and seed index (0.633) had a significant positive association with seed cotton yield per plant. Hence selection for these traits will help in selecting genotypes with higher seed cotton yield. Such positive association of seed cotton yield per plant with these traits was also observed by Sunayana et al., (2017). Pujer et al., (2014) reported the same results for plant height, number bolls per plant and seed index and Asha et al., (2015) for plant height, number of sympodia per plant, number bolls per plant, boll weight, upper half mean length, bundle strength and fibre elongation. The traits like days to first flowering, days to fifty percent flowering, number of sympodia per plant, lint index and fibre fineness exhibited nonsignificant association with seed cotton yield. Similar results were reported by Asha et al., (2015) for days to fifty percent flowering, lint index and fibre fineness; Sunayana et al., (2017) for lint index. In the present study number of monopodia per plant showed significant negative association with seed cotton yield but contradictory to the results obtained in the present study, Asha et al., (2015) reported non-significant positive association. Although positive (fibre fineness) and negative associations (fibre strength and fibre elongation) with seed cotton yield were observed in the present study, none was found to be significant in any of the crosses studied. Rao et al., (2001) and Echekwu (2001) have observed significant positive association of these traits with seed cotton yield.

\section{Correlation of characters inter se}

Significant and positive inter genotypic correlation between the quantitative yield contributing traits were observed viz., days to first flowering with days to fifty percent flowering, plant height, number of sympodia per plant; days to fifty percent flowering with plant height, number of sympodia per plant; Plant height with number of sympodia per plant, number of bolls per plant: Number of monopodia per plant with upper half mean length; number of bolls per plant with seed index; Boll weight with seed index and lint index; seed index with fibre fineness; lint index with ginning percentage were positive and significant indicating the possibility of simultaneous improvement of these traits. Days to first flowering and days to fifty percent flowering with lint index and ginning percentage; Number of monopodia per plant with number of bolls per plant; seed index with ginning percentage has significant negative inter correlation.

The fibre quality traits exhibited positive inter correlation among themselves and some of these showing significance like upper half mean length with bundle strength and uniformity index: bundle strength with uniformity index and fibre elongation; fibre fineness with fibre elongation. In the present study, genotypic correlation coefficient were higher than phenotypic correlation coefficient for all traits studied except days to fifty percent flowering which revealed that there was strong genetic association between these characters but the phenotypic value lessened by the significant interaction of environment. Hence, selection based on plant height, number of bolls per plant, boll weight and seed index along with quality traits upper half mean length and bundle strength will bring about breakthrough in cotton yields

\section{Path co-efficient studies}

The study of path coefficients enable breeder to concentrate on the variables which show high direct effect on seed cotton yield. The genotypic correlation coefficient of seed cotton yield with other yield contributing and fibre quality traits were further partitioned into direct and indirect effects (Table 4). 
Table.1 Analysis of variance for various yield components and fibre quality traits

\begin{tabular}{|c|c|c|c|c|c|c|c|c|c|c|c|c|c|c|c|c|c|}
\hline $\begin{array}{l}\text { Source of } \\
\text { Variation }\end{array}$ & DF & DFF & DFPF & PH & NMP & NSyP & NB & BW & SI & LI & GP & UHML & BS & FF & UI & FE & SCYP \\
\hline Replication & 2 & 2.70 & 3.17 & 23.30 & 0.01 & 0.72 & 8.14 & 0.29 & 2.04 & 0.69 & 0.36 & 0.20 & 0.01 & 0.07 & 0.12 & 0.16 & 15280.64 \\
\hline Genotypes & 34 & $9.36^{*}$ & $9.74^{*}$ & $92.35^{*}$ & $0.32 *$ & $1.40^{*}$ & $45.96^{*}$ & $0.37 *$ & $1.47^{*}$ & $0.87^{*}$ & $18.68 *$ & $1.95^{*}$ & $1.53 *$ & $0.32 *$ & $0.55^{*}$ & $0.02 *$ & $539855.18 *$ \\
\hline Error & 64 & 1.25 & 1.64 & 20.18 & 0.02 & 0.73 & 3.36 & 0.08 & 0.79 & 0.26 & 3.01 & 0.004 & 0.01 & 0.004 & 0.01 & 0.01 & 25879.45 \\
\hline
\end{tabular}

Table.2 Genetic components of variance for various quantitative traits

\begin{tabular}{|c|c|c|c|c|c|c|c|c|c|c|c|c|c|c|c|c|}
\hline Traits & DFF & DFPF & PH & $\mathbf{N M / P}$ & Nsy/P & $\mathbf{N B} / \mathbf{P}$ & BW & SI & LI & GP & UHML & BS & FF & UI & FE & SCY \\
\hline G. Mean & 51.04 & 54.36 & 97.24 & 0.58 & 13.84 & 22.84 & 4.58 & 9.4 & 5.71 & 37.83 & 26.92 & 27.75 & 4.48 & 83.27 & 5.59 & 1774.1 \\
\hline PV & 3.83 & 4.31 & 43.65 & 0.13 & 1.1 & 17.03 & 0.18 & 1.05 & 0.45 & 8.13 & 0.71 & 0.51 & 0.12 & 0.18 & 0.01 & 193440.2 \\
\hline GV & 2.63 & 2.77 & 22.78 & 0.11 & 0.38 & 13.64 & 0.1 & 0.22 & 0.19 & 5.09 & 0.71 & 0.5 & 0.11 & 0.17 & 0.004 & 167141.2 \\
\hline PCV & 3.83 & 3.82 & 6.79 & 61.17 & 7.59 & 18.07 & 9.37 & 10.9 & 11.74 & 7.54 & 3.13 & 2.56 & 7.64 & 0.51 & 1.72 & 24.79 \\
\hline GCV & 3.18 & 3.06 & 4.91 & 56.64 & 4.47 & 16.17 & 6.84 & 4.97 & 7.57 & 5.96 & 3.12 & 2.54 & 7.52 & 0.5 & 1.17 & 23.04 \\
\hline h2 (\%) & 68.7 & 64.1 & 52.2 & 85.8 & 34.7 & 80.1 & 53.4 & 20.8 & 41.6 & 62.6 & 99.5 & 98 & 96.8 & 96.5 & 46.3 & 86.4 \\
\hline GAM & 5.43 & 5.05 & 7.3 & 108.05 & 5.42 & 29.8 & 10.3 & 4.66 & 10.05 & 9.72 & 6.42 & 5.18 & 15.24 & 1.01 & 1.64 & 44.13 \\
\hline
\end{tabular}

Table.3 Genotypic and phenotypic correlations of various quantitative traits

\begin{tabular}{|c|c|c|c|c|c|c|c|c|c|c|c|c|c|c|c|c|}
\hline Traits & DFF & DFPF & PH & NM/P & Nsy/P & NB/P & BW & SI & LI & GP & UHML & BS & FF & UI & FE & SCY \\
\hline \multirow[t]{2}{*}{ DFF } & 1.000 & $0.977 *$ & $0.370 *$ & 0.219 & $0.360 *$ & 0.255 & -0.199 & 0.279 & $-0.581 *$ & $-0.611^{*}$ & 0.068 & 0.011 & 0.161 & -0.198 & 0.190 & 0.116 \\
\hline & 1.000 & $0.855^{*}$ & 0.200 & 0.137 & 0.081 & 0.169 & -0.090 & 0.133 & -0.279 & $-0.403 *$ & 0.050 & 0.014 & 0.121 & -0.169 & 0.148 & 0.098 \\
\hline \multirow[t]{2}{*}{ DFPF } & & 1.000 & $0.525 *$ & 0.152 & $0.393^{*}$ & 0.183 & -0.271 & 0.084 & $-0.742 *$ & $-0.642 *$ & -0.017 & -0.062 & -0.006 & -0.243 & 0.277 & 0.052 \\
\hline & & 1.000 & 0.217 & 0.080 & 0.123 & 0.136 & -0.107 & 0.033 & $-0.419 *$ & $-0.448^{*}$ & -0.012 & -0.044 & 0.001 & -0.201 & 0.099 & 0.059 \\
\hline \multirow[t]{2}{*}{ PH } & & & 1.000 & -0.095 & $0.695^{*}$ & $0.660 *$ & 0.142 & 0.288 & -0.210 & -0.323 & -0.223 & -0.036 & 0.013 & -0.121 & -0.161 & $0.443 *$ \\
\hline & & & 1.000 & -0.007 & 0.443* & $0.427 *$ & 0.053 & -0.037 & -0.265 & -0.222 & -0.163 & -0.044 & -0.016 & -0.112 & -0.002 & 0.332 \\
\hline
\end{tabular}




\begin{tabular}{|c|c|c|c|c|c|c|c|c|c|c|c|c|c|}
\hline \multirow[t]{2}{*}{ NM/P } & 1.000 & 0.090 & $-0.362 *$ & -0.234 & -0.133 & 0.043 & 0.086 & $0.428 *$ & 0.260 & -0.041 & 0.252 & 0.046 & $-0.361 *$ \\
\hline & 1.000 & 0.104 & -0.288 & -0.165 & -0.056 & 0.018 & 0.058 & 0.398* & 0.238 & -0.027 & 0.235 & 0.030 & -0.321 \\
\hline \multirow[t]{2}{*}{ Nsy/P } & & 1.000 & 0.291 & -0.190 & 0.065 & -0.131 & -0.168 & -0.228 & 0.101 & 0.327 & 0.222 & 0.114 & -0.045 \\
\hline & & 1.000 & 0.244 & -0.004 & 0.023 & -0.136 & -0.145 & -0.133 & 0.069 & 0.215 & 0.125 & $-\mathbf{0 . 0 3 5}$ & 0.020 \\
\hline \multirow[t]{2}{*}{ NB/P } & & & 1.000 & 0.273 & $0.488^{*}$ & -0.106 & -0.326 & -0.215 & -0.103 & 0.322 & -0.243 & 0.020 & $0.824^{*}$ \\
\hline & & & 1.000 & 0.220 & 0.267 & -0.019 & -0.241 & -0.198 & -0.086 & 0.272 & -0.217 & 0.001 & $0.688 *$ \\
\hline \multirow[t]{2}{*}{ BW } & & & & 1.000 & $0.727^{*}$ & $0.377^{*}$ & -0.075 & 0.028 & -0.093 & -0.037 & 0.000 & -0.286 & $0.467^{*}$ \\
\hline & & & & 1.000 & $0.495 *$ & 0.388* & -0.060 & 0.021 & -0.061 & -0.051 & -0.010 & -0.098 & 0.333 \\
\hline \multirow[t]{2}{*}{ SI } & & & & & 1.000 & -0.115 & $-0.614^{*}$ & 0.038 & -0.071 & $0.434 *$ & 0.046 & 0.087 & $0.633^{*}$ \\
\hline & & & & & 1.000 & $0.425 *$ & $-0.472 *$ & 0.017 & -0.021 & 0.186 & 0.026 & 0.012 & 0.269 \\
\hline \multirow[t]{2}{*}{$\mathbf{L I}$} & & & & & & 1.000 & $0.853 *$ & -0.079 & 0.127 & 0.309 & 0.271 & -0.109 & 0.129 \\
\hline & & & & & & 1.000 & 0.593 & -0.052 & 0.084 & 0.182 & 0.186 & -0.034 & 0.089 \\
\hline \multirow[t]{2}{*}{ GP } & & & & & & & 1.000 & -0.063 & 0.158 & 0.020 & 0.204 & -0.141 & -0.209 \\
\hline & & & & & & & 1.000 & -0.052 & 0.115 & 0.010 & 0.166 & -0.039 & -0.140 \\
\hline \multirow[t]{2}{*}{ UHML } & & & & & & & & 1.000 & $0.586^{*}$ & -0.348 & $0.561 *$ & 0.159 & -0.294 \\
\hline & & & & & & & & 1.000 & $0.578 *$ & -0.342 & $0.548 *$ & 0.108 & -0.272 \\
\hline \multirow[t]{2}{*}{ BS } & & & & & & & & & 1.000 & -0.069 & $0.661 *$ & $0.604^{*}$ & -0.239 \\
\hline & & & & & & & & & 1.000 & -0.061 & $0.662 *$ & 0.359* & -0.224 \\
\hline \multirow[t]{2}{*}{ FF } & & & & & & & & & & 1.000 & -0.171 & $0.466^{*}$ & 0.127 \\
\hline & & & & & & & & & & 1.000 & -0.151 & 0.233 & 0.116 \\
\hline \multirow[t]{2}{*}{ UI } & & & & & & & & & & & 1.000 & 0.072 & -0.316 \\
\hline & & & & & & & & & & & 1.000 & -0.054 & -0.292 \\
\hline \multirow[t]{2}{*}{ FE } & & & & & & & & & & & & 1.000 & -0.263 \\
\hline & & & & & & & & & & & & 1.000 & -0.154 \\
\hline
\end{tabular}

* Significant at 5\% level. The values in bold are phenotypic correlation 
Table.4 Direct effects and indirect effects of various traits on seed cotton yield at genotypic level

\begin{tabular}{|c|c|c|c|c|c|c|c|c|c|c|c|c|c|c|c|c|}
\hline Traits & DFF & FPF & PH & $\mathrm{JM} / \mathbf{P}$ & sy/P & $\mathrm{NB} / \mathrm{P}$ & BW & SI & LI & GP & UHML & BS & FF & UI & FE & SCY \\
\hline DFF & 2.748 & .572 & 0.883 & .268 & 871 & .055 & 642 & 2.853 & 2.334 & 15.020 & -0.006 & 0.007 & 0.181 & .028 & 0.072 & 0.116 \\
\hline DFPF & 685 & 633 & 253 & .187 & 951 & 039 & 374 & 61 & .756 & .770 & .002 & .040 & 006 & 035 & 105 & .052 \\
\hline PH & 1.017 & & 2387 & & 583 & 142 & 457 & & & 6 & 9 & .023 & -0.015 & 0.017 & 0.061 & $0.443^{*}$ \\
\hline NM/P & 0.601 & 400 & .227 & -1.227 & .218 & 0.078 & 0.753 & 1.357 & 910 & -2.111 & -0.036 & 0.168 & 0.046 & 0.036 & -0.017 & $0.361 *$ \\
\hline Nsy/P & 0.988 & .034 & 1.659 & -0.110 & -2.422 & .063 & 0.614 & -0.663 & -2.788 & 4.133 & 0.019 & 0.065 & -0.368 & -0.032 & -0.043 & -0.045 \\
\hline $\mathbf{N B} / \mathbf{P}$ & 0.700 & -0.482 & 1.575 & 0.445 & -0.704 & .215 & -0.881 & -4.995 & -2.253 & 8.019 & 0.018 & -0.066 & -0.363 & 0.035 & -0.008 & $0.824 *$ \\
\hline BW & -0.548 & 0.714 & 0.339 & 0.287 & 0.461 & .059 & -3.223 & -7.439 & 8.006 & 1.841 & -0.002 & -0.060 & 0.042 & 0.000 & 0.108 & $0.467 *$ \\
\hline SI & 767 & 222 & 0.687 & 0.163 & -0.157 & .105 & -2.344 & -10.228 & -2.446 & 15.095 & -0.003 & -0.046 & -0.489 & -0.007 & -0.033 & $0.633^{*}$ \\
\hline LI & 596 & 53 & -0.502 & 0.053 & 0 & 0.023 & 15 & 1. & 21. & -20.957 & 97 & 0.082 & -0.348 & -0.039 & .041 & 0.129 \\
\hline GP & 680 & 1.690 & -0.771 & -0.105 & 0 . & 0 & 2 & 4 & 15 & -24.569 & 0.005 & 0.102 & -0.023 & -0.029 & 0.053 & -0.209 \\
\hline UHML & 0.185 & 0.046 & -0.533 & -0.526 & 0.552 & 46 & -0.092 & -0.385 & -1.674 & 1.540 & -0.083 & 0.378 & 0.392 & -0.080 & -0.060 & -0.294 \\
\hline BS & 0.030 & 0.164 & -0.085 & -0.319 & -0.244 & 0.022 & 0.300 & 0.729 & 2.690 & -3.878 & -0.049 & 0.645 & 0.077 & -0.094 & -0.228 & -0.239 \\
\hline FF & 0.442 & 0.015 & 0.031 & 0.050 & -0.792 & .069 & 0.121 & -4.438 & 6.554 & -0.492 & 0.029 & -0.044 & -1.126 & 0.024 & -0.176 & 0.127 \\
\hline UI & -0.545 & 0.639 & -0.289 & -0.309 & -0.537 & 0.052 & 0.000 & -0.468 & 5.757 & -5.017 & -0.047 & 0.426 & 0.193 & -0.142 & -0.027 & -0.316 \\
\hline FE & 0.522 & -0.729 & -0.384 & -0.056 & -0.275 & -0.004 & 0.921 & -0.886 & -2.310 & 3.475 & -0.013 & 0.390 & -0.525 & -0.010 & -0.377 & -0.263 \\
\hline
\end{tabular}

Residual Effect: 0.6108 
It was indicated that days to first flowering (2.748), plant height (2.387), lint index (21.236) have positive and very high direct effect on seed cotton yield whereas bundle strength have positive and high direct on seed cotton yield. Pujer et al., (2014) was reported the similar result for days to first flowering and lint index. In the present study, positive and high indirect effect on seed cotton yield exhibited by days to first flowering through plant height, boll weight and ginning percentage; days to fifty percent flowering through days to first flowering, plant height, boll weight, ginning percentage; plant height via days to first flowering, ginning percentage; number of monopodia per plant via days to first flowering, boll weight, seed index, lint index; number sympodia per plant through days to first flowering, plant height, boll weight, ginning percentage; number of bolls per plant via days to first flowering, plant height, number of monopodia per plant, ginning percentage; seed index through days to first flowering, ginning percentage; lint index via days to fifty percent flowering, seed index; ginning percentage through days to fifty percent flowering, number of sympodia per plant, seed index, lint index.

In conclusion, high heritability observed for days to first flowering, days to fifty percent flowering, number of monopodia per plant, number of bolls per plant, ginning percentage, upper half mean length, bundle strength, fibre fineness, uniformity index and seed cotton yield. Number of monopodia per plant, number of bolls per plant and seed cotton yield per plant shows high heritability coupled with high genetic advance over mean indicating the preponderance of additive gene action in the inheritance of these traits. The traits such as days to first flowering, days to fifty percent flowering, ginning percentage, ginning percentage, upper half mean length, bundle strength and uniformity index in which high heritability accompanied by low genetic advance was recorded indicates the effect of non additive gene action and hence heterosis breeding may be rewarding for these traits. Association analysis revealed that simultaneous selection based on days to first flowering, plant height, number of bolls per plant, boll weight, seed index and lint index will bring about breakthrough in cotton yield.

\section{References}

Al-Jibouri, HA, Miller, PA and Robinson, HF. 1958. Genotypic and environmental variances and co-variances in upland cotton crosses of inter specific origin. Agron. J., 50: 633-637.

Allard, R. W. (1960). Principles of Plant Breeding. Publishers by John Wiley and Sons Inc. New York, USA: pp. 485.

Asha, R, Ahamed, ML, Babu, DR and Kumar, PA. 2015. Character association and path coefficient analysis for yield and component traits in upland cotton. $J$. Cotton Res. and Dev., 29 (1): 31-35.

Burton, GW and DeVane, EW. 1953. Estimating heritability in tall fescue (Feetuca circuhinoceae) from replicated clonal material. Agron. J., 45: 478-481.

Dewey, DR and Lu, KH. 1959. A correlation and path coefficient analysis of components of crested wheat grass seed Production. Agron. J., 51: 515-518.

Doak, C.C. (1934). A new technique in hybridizing suggested changes in existing methods of emasculation and bagging cotton flowers. J. Hered., 25: 201-204.

Echekwu, C.A. (2001). Correlations and correlated responses in upland cotton (Gossypium hirsutum L.). Tropicultura. 19(4): 210-213.

Eswari, K.B., Sudheer Kumar, S., Gopinath and Rao, M.V.B. (2017). Genetic variability heritability and genetic advance studies in cotton. International 
Journal of Development Research: Vol. 07, Issue, 01, pp.10902-10904.

Falconer, D.S., Introduction to quatitative genetics. Second edition. Longman, New York. (1981)

Gnanasekaran, M., Thiyagu, K. and Gunasekaran, M..2018. Genetic variability heritability and genetic advance studies in cotton (Gossypium hirsutum 1.) Electronic Journal of Plant Breeding, 9(1): 377 - 382 .

Hanson, C.H.; Robinson, H.F. and Comstock, R.E.1956. Biometrical studies of yield in segregating population of Korean lespendeza. Agron. J., 48: 267-282.

Johanson, HW, Robinson, $\mathrm{H}$ and Comstock, RE. 1955. Estimates of genetic and environmental variability in soybean. Agron. J., 47: 314 - 318.

Panse, V.G. (1957). Genetics of quantitative characters in relation to plant breeding. Indian Journal of Genetics and Plant Breeding, 17(3): 318-328.

Praveen Sampath Kumar., C, Raju, S., Ebenezer Babu Rajan,, Ajish Muraleedharan, $\mathrm{R}$ and Darling B. Suji.2019. Studies on genetic variability, heritability and genetic advance in cotton (Gossypium hirsutum l.). Plant Archives Vol. 19, Supplement 1, 2019 pp. 934-937
Pujer, SK, Siwach, SS, Sangwan, RS, Sangwan, O and Deshmukh, J. 2014. Correlation and path coefficient analysis for yield and fibre quality traits in upland cotton (Gossypium hirsutum L.). J. Cotton Res. and Dev., 28 (2): 214216.

Rama Reddy, Y and Sarma, A. S. R. 2014. Plant Archives Vol. 14 (1): 2014 pp. 417-419

Rao, GN, Reddy, MSS and Shanthi, P. 2001. Correlation and path analysis of seed cotton yield and its components in cotton. J. Cotton Res. Dev., 15: 81-83.

Sunayana, R., Sangwan, S and Somveer Nimbal. 2017. Studies on Association, Path Analysis and Genetic Parameters for Seed Cotton Yield and Its Contributing Characters in Desi Cotton (Gossypium arboreum L.). Int.J.Curr.Microbiol.App.Sci. 6 (11): 104-111.doi:

https://doi.org/10.20546/ijcmas.2017.61 1.013

Swarup, V. and Chaugale, B. S. 1962. Studies on genetic variability in sorghum. Phenotypic variation and heritable component in some quantitative characters contributing towards yield. Indian Journal of Genetics and Plant Breeding 22: 31-36.

\section{How to cite this article:}

Gnanasekaran, M. and Thiyagu, K. 2020. Selection Parameters for Improving the Seed Cotton Yield and Fibre Quality Traits in American Cotton (Gossypium hirsutum L.). Int.J.Curr.Microbiol.App.Sci. 9(10): 1333-1342. doi: https://doi.org/10.20546/ijcmas.2020.910.160 